\title{
Badanie skuteczności inhibitorów osadów nieorganicznych za pomocą testu dynamicznego symulującego warunki wydobycia i transportu ropy naftowej
}

\author{
Study of the effectiveness of inorganic scale inhibitors by means of a dynamic test \\ simulating the conditions of oil extraction and transport
}

\author{
Jerzy Kuśnierczyk, Wojciech Mazela \\ Instytut Nafty i Gazu - Państwowy Instytut Badawczy
}

\begin{abstract}
STRESZCZENIE: Osady nieorganiczne mogą występować jako jednorodne mineralne struktury, jednak w większości przypadków są to twory składające się z różnego rodzaju składników. Istnieje znaczne ryzyko wytrącania się takich osadów na różnych etapach wydobycia ropy naftowej ze złoża czy zabiegów intensyfikacyjnych oraz w trakcie transportu ropy. Osady mogą odkładać się na każdym etapie, nawet w złożu lub w strefie przyodwiertowej, a w dalszej kolejności również w rurociągach, na zakończeniach urządzeń wydobywczych oraz na ich powierzchni, np. w separatorze. Tworzenie się osadów może prowadzić do: zmniejszania przepuszczalności złoża, utrudnienia lub nawet zablokowania przepływu płynów w rurach wydobywczych, uszkodzenia urządzeń wydobywczych oraz do wielu innych problemów związanych z eksploatacją złoża (Frenier i Ziauddin, 2008). Gromadzenie się osadów nieorganicznych w różnych częściach urządzeń wydobywczych jest jednym z największych problemów związanych z eksploatacją. Aby spowolnić, opóźnić lub w znacznym stopniu zminimalizować ten proces, optymalnym rozwiązaniem jest zastosowanie odpowiednich inhibitorów (Kuśnierczyk, 2017). Metoda taka jest efektywna, stosunkowo prosta i ekonomicznie uzasadniona. Istnieją zarówno inhibitory ograniczające wytrącanie się soli, takich jak $\mathrm{CaCO}_{3}$ i $\mathrm{BaSO}_{4}$ (Luo et al., 2015), jak też inhibitory ograniczające procesy korozji, których obecność sprzyja wytrącaniu się osadów związków żelaza (Tiu i Advincula, 2015). Substancje te, oprócz inhibitorów parafin (Gaździk i Pajda, 2013) i hydratów oraz demulgatorów (Mazela et al., 2012; Pajda et al., 2013), stanowią podstawową grupę środków chemicznych stosowanych w przemyśle naftowym (ang. production chemicals). Dobór skutecznego inhibitora wymaga przeprowadzenia testów uwzględniających zarówno skład solanki, jak i warunki, takie jak: temperatura, ciśnienie i szybkość przepływu. W artykule przedstawiono budowę stanowiska, które zostało użyte do prowadzenia testów w warunkach dynamicznych. Zaprezentowano także wyniki badań dla kilku inhibitorów osadów, zarówno wykorzystywanych w przemyśle, jak też stworzonych na potrzeby prowadzonych badań.
\end{abstract}

Słowa kluczowe: osady węglanu wapnia, inhibitory osadów nieorganicznych, dynamiczny test blokowania kapilary.

ABSTRACT: Inorganic deposits may occur as homogeneous mineral structures, but in most cases they are compositions made up of various types of ingredients. There is a significant risk of such sediments precipitating at various stages of oil extraction from the deposit, or also intensification measures and during the transport of oil. Sludges can be deposited at any stage, even in a bed or in the near-well zone. Subsequently, also in pipelines, at the ends of mining equipment and on their surface, e.g. in a separator. The formation of sediments may lead to: decreasing the permeability of the deposit, hindering or even blocking the flow of fluids in the mining pipes, damage to mining equipment, and many other problems related to the exploitation of the deposit (Frenier and Ziauddin, 2008). The accumulation of inorganic deposits in various parts of mining equipment is one of the biggest problems associated with exploitation. To slow down, delay or significantly minimize this process, the optimal solution is to use appropriate inhibitors (Kuśnierczyk, 2017). This method is effective, relatively simple, and economically justified. There are inhibitors that limit the precipitation of salts, such as $\mathrm{CaCO}_{3}$ and $\mathrm{BaSO}_{4}\left(\mathrm{Luo}_{\mathrm{C}}\right.$ et al., 2015), as well as inhibitors that limit corrosion processes, the presence of which promotes the precipitation of iron compounds (Tiu and Advincula, 2015). These substances, in addition to paraffin inhibitors (Gaździk and Pajda, 2013), hydrates and demulsifiers (Mazela et al., 2012, Pajda et al., 2013), constitute the basic group of chemicals used in the oil industry (production chemicals). The selection of an effective inhibitor requires tests that take into account both the brine composition and the conditions such as temperature, pressure and flow rate. The article presents the construction of the station, which was used to conduct tests in dynamic conditions. The results of tests for several sludge inhibitors, both used in industry as well as those created for the needs of research, are also presented.

Key words: calcium carbonate scale, inorganic scale inhibitors, Tube Blocking Test

Autor do korespondencji: J. Kuśnierczyk, e-mail: jerzy.kusnierczyk@inig.pl

Artykuł nadesłano do Redakcji 21.12.2018 r. Zatwierdzono do druku 27.05.2019 r. 


\section{Wstęp}

W przemyśle naftowym najczęściej stosuje się dwie podstawowe metody oceny inhibitorów osadów nieorganicznych: statyczny test butelkowy, opisany w NACE Standard Test Method TM0374-2007 oraz dynamiczny test blokowania kapilary (ang. tube blocking test), przedstawiony w NACE 31105 , No. 24225. W literaturze można spotkać zarówno modyfikacje tych metod, jak też inne sposoby oceny inhibitorów, mające na celu lepsze odwzorowanie warunków przemysłowych, w jakich inhibitor będzie stosowany, lub też lepsze poznanie zjawisk zachodzących podczas inhibitowania. Ocena inhibitorów ma na celu wybór najbardziej skutecznego inhibitora do określonego zastosowania oraz wyznaczenie minimalnego jego stężenia MIC (ang. minimum inhibitor concentration) (Mazela i Kuśnierczyk, 2018).

\section{Test dynamiczny TBT}

Dynamiczny test blokowania kapilary (TBT) polega na jednoczesnym tłoczeniu z odpowiednią wydajnością dwóch solanek (anionowej oraz kationowej) przez kapilarę posiadającą określone parametry (długości oraz średnicy wewnętrznej) w zadanych warunkach PT (ciśnienia i temperatury). Podgrzewanie płynących w oddzielnych przewodach solanek ma miejsce w termostacie. Znajduje się tam również kapilara, do której wtłaczane są obie solanki po zmieszaniu. Ciśnienie różnicowe $(\Delta \mathrm{P})$ na całej długości kapilary jest monitorowane w punkcie mieszania, przed wejściem do kapilary oraz na wyjściu. Wytrącanie się osadów powoduje wzrost $\Delta \mathrm{P}$ w kapilarze, który jest zwykle rejestrowany na wykresie w funkcji czasu (Kuśnierczyk, 2018).

Średnica wewnętrzna kapilary używanej w trakcie badań powinna być w granicach od 0,05 $\mathrm{mm}$ do $1,7 \mathrm{~mm}$. Najczęściej stosowane średnice to $1,0 \mathrm{~mm}$ i 1,1 $\mathrm{mm}$. Materiałem, z jakiego na ogół wykonuje się kapilarę, jest stal 316 SS. Długość kapilary waha się w granicach od $50 \mathrm{~mm}$ do $15 \mathrm{~m}$, jednak najczęściej stosuje się kapilary o długości 1 m (Hamouda, 1989; Todd et al., 2012; Szymczak et al., 2013; Schilter et al., 2014).

Według części badaczy wystarczające jest zastosowanie ciśnienia, które pozwala na przetłoczenie solanek przez kapilarę, w innych przypadkach wykorzystywano znacznie wyższe ciśnienie. Podwyższenie ciśnienia wynikało prawdopodobnie $\mathrm{z}$ dążenia do odzwierciedlenia warunków, w jakich znajduje się solanka w odwiercie, lub utrzymania stężenia rozpuszczonych gazów (Hamouda, 1989; Schalge i Dormish, 1989; Oddo et al., 1993; Khormali et al., 2017).

Często w literaturze badania blokowania kapilary prowadzone są bezciśnieniowo, czyli na tzw. wolny wypływ
(Bazin et al., 2004; Senthilmurugan et al., 2011; Shanthana Lakshmi et al., 2013). Można wtedy zaobserwować wzrost ciśnienia w trakcie tłoczenia solanek, gdy w kapilarze zaczyna wytrącać się osad. Spotyka się również badania prowadzone pod ciśnieniem wyższym niż atmosferyczne. Od niewielkiego ciśnienia wstecznego rzędu 13 bar (Liu et al., 2012) - 17 bar (Graham et al., 2002) do niekiedy 80 bar (Jensen i Kelland, 2012) i wyższego.

Prędkość tłoczenia solanek przez kapilarę również waha się w bardzo szerokim zakresie. W niektórych przypadkach jest to tylko $0,25 \mathrm{ml} / \mathrm{min}$ dla poszczególnych solanek (Bazin et al., 2004), tłoczonych jednak przez długi czas, dochodzący do 22 godzin. Natomiast w innej publikacji opisano natężenie przepływu pomiędzy 17 a $67 \mathrm{ml} / \mathrm{min} \mathrm{w}$ aparacie z kapilarą o średnicy 1,1 mm (Cushner et al., 1988).

W trakcie testu dynamicznego tłoczy się dwa rodzaje solanek w tym samym czasie. Są to solanki na ogół syntetyczne, o znanym składzie z jonami anionowymi i kationowymi. W literaturze dobór prędkości przepływu zależy od możliwości posiadanej aparatury oraz założeń przyjętych przez autora. Na ogół przetłacza się obie solanki z tą samą prędkością, czyli stosunek solanki anionowej do kationowej wynosi 50:50 (Graham et al., 2002; Bazin et al., 2004; Senthilmurugan et al., 2011; Jensen i Kelland, 2012; Liu et al., 2012; Shanthana Lakshmi et al., 2013).

W różnych opracowaniach najczęściej podawany przedział temperatury waha się od $70^{\circ} \mathrm{C}$ do $90^{\circ} \mathrm{C}$, co ma związek z dążeniem do odwzorowania warunków przemysłowych. Korzystne jest, aby aparat umożliwiał wykonywanie testów w szerokim zakresie temperatur, na przykład od $-18^{\circ} \mathrm{C}$ do $150^{\circ} \mathrm{C}$, co pozwala lepiej odwzorować warunki przemysłowe i skrócić czas doboru właściwego inhibitora.

\section{Stanowisko badawcze do testu dynamicznego}

Badania dotyczące oceny skuteczności inhibitorów osadów nieorganicznych prowadzono z wykorzystaniem bezrtęciowej aparatury PVT do badań właściwości fazowych płynów złożowych. Dla realizacji tych badań zestaw PVT został odpowiednio rozbudowany dodatkowo o szereg połączeń wysokociśnieniowych oraz ultratermostat służący do utrzymania zadanej temperatury (rys. 1).

Głównym elementem aparatury użytym do badań była kapilara wykonana ze stali 316 SS. Kapilara posiadała długość 2,30 m oraz średnicę $0,9 \mathrm{~mm}$, które są zgodne z procedurą NACE. Modernizacja aparatury polegała na zamontowaniu tej kapilary w łaźni ultratermostatu wypełnionego wodą. Ultratermostat dodatkowo umożliwił precyzyjną regulację temperatury przepływających solanek. Zawór mieszający 


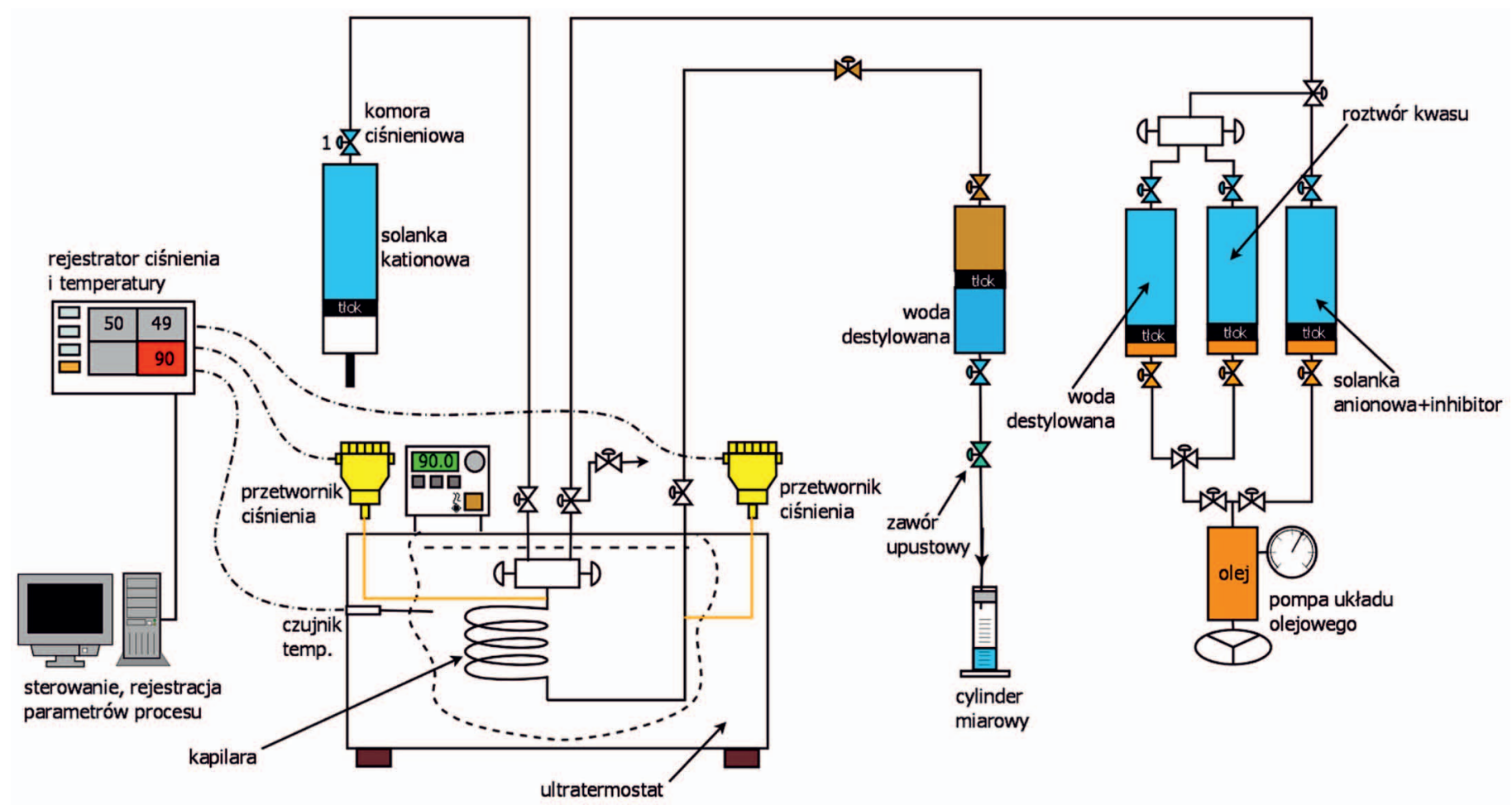

Rys. 1. Schemat zastosowanego układu pomiarowego

Fig. 1. Diagram of the applied measurement system

obie solanki był całkowicie zanurzony w cieczy. Następowało w nim zmieszanie solanek anionowej i kationowej, które następnie przetłaczano przez kapilarę aż do momentu zablokowania przepływu. Wytrącanie się osadów objawia się wzrostem ciśnienia w układzie, który powodowany jest przywieraniem osadu do ścianek kapilary i blokowaniem przepływu. Po wykonaniu testu następuje przemycie kapilary odpowiednim roztworem kwasu, pozwalającym na usunięcie osadu i przygotowanie układu do kolejnego testu.

Niejednokrotnie aparatura wyposażona jest w elektroniczne czujniki, które automatycznie wyłączają pompy, gdy różnica ciśnień na kapilarze przekroczy założony poziom wskazujący na blokowanie kapilary. Przedstawiony na rysunku 1 układ pomiarowy posiada regulator ciśnienia wstecznego. Jest on używany do utrzymywania ciśnienia w zwoju rurki kapilarnej.

W tabeli 1 przedstawiono skład jonowy solanek, z których po zmieszaniu, w sprzyjających warunkach, następuje wytrącanie się węglanu wapnia. Jedna z nich zawiera aniony zdolne do tworzenia wytrącających się soli, natomiast druga zawiera odpowiednie kationy. Oddzielnie mają nieznaczną skłonność do wytrącania osadów. Solanki przygotowano z użyciem wody destylowanej; po dodaniu i rozpuszczeniu się soli każdą z solanek przesączono przez filtr membranowy o średnicy porów 0,45 mikrometra. Bezpośrednio przed testem solanki odgazowano, umieszczając je w myjce ultradźwiękowej na 30 minut. Jako solanki testowe niejednokrotnie stosuje się
Tabela 1. Skład solanek zastosowanych do oceny inhibitowania węglanu wapnia (Kuśnierczyk, 2017)

Table 1. Composition of brines used to assess calcium carbonate inhibition (Kuśnierczyk, 2017)

\begin{tabular}{|c|c|c|}
\hline \multirow{2}{*}{ Jony } & \multicolumn{2}{|c|}{$\begin{array}{c}\text { Stężenie jonów w solance } \\
\text { [mg/l] }\end{array}$} \\
\cline { 2 - 3 } & Solanka kationowa & Solanka anionowa \\
\hline \hline $\mathrm{Na}^{+}$ & 27521 & 27550 \\
\hline $\mathrm{Ca}^{2+}$ & 16090 & - \\
\hline $\mathrm{Mg}^{2+}$ & 2048 & - \\
\hline $\mathrm{Cl}^{-}$ & 77023 & 42480 \\
\hline $\mathrm{HCO}_{3}^{-}$ & - & 2230 \\
\hline
\end{tabular}

solanki pochodzące z kopalni, dla których skłonność do wytrącania się osadów baru i strontu jest już znana lub stanowi przedmiot oceny (Mazela i Kuśnierczyk, 2018).

Przed właściwymi testami pozwalającymi oceniać inhibitory konieczne jest dobranie takich parametrów testu jak skład solanek, szybkość ich przepływu, temperatura i ciśnienie. Z uwagi na różnorodną budowę układów, w tym wymiary stosowanych kapilar, parametry te należy każdorazowo dobrać do stosowanego układu pomiarowego. Czas blokowania kapilary nie powinien być zbyt krótki, co może mieć wpływ na stabilizację warunków testu, ani też zbyt długi, co podyktowane jest względami praktycznymi. Najczęściej za odpowiedni przyjmuje się czas rzędu kilkunastu minut (Mazela i Kuśnierczyk, 2018). 
W trakcie wstępnych badań ustalono próbę zerową na poziomie 16 minut. Warunki, w jakich dokonywano pomiaru, za każdym razem były takie same: ciśnienie na poziomie 50 bar, temperatura $90^{\circ} \mathrm{C}$, natomiast przepływ sumaryczny wynosił $2 \mathrm{~cm}^{3} / \mathrm{min}$. Aby stwierdzić skuteczność inhibitora, tłoczono mieszaninę solanek przez pięciokrotność próby zerowej, czyli w tym przypadku przez 80 minut.

\section{Test inhibitora $\mathrm{nr} 1$}

Po zakończeniu wstępnych badań w celu określenia próby zerowej, z użyciem solanek węglanowych, przystąpiono do badania skuteczności działania inhibitorów osadów. Zostały one pozyskane przez autorów z różnych źródeł. Jednym z takich inhibitorów jest środek oznaczony jako nr 1. To produkt handlowy, którego głównym składnikiem jest poli(kwas asparaginowy) o średniej masie cząsteczkowej wynoszącej 3000 daltonów. Produkt jest nietoksyczny, przyjazny dla środowiska, biodegradowalny i nieulegający bioakumulacji. Wykazuje właściwości inhibitora korozji oraz inhibitora osadów siarczanowych i węglanowych. Został on przebadany w trzech stężeniach: 20 ppm, 30 ppm i 40 ppm. Do solanki anionowej dodawano inhibitora, zwiększając stopniowo jego stężenie, aż do momentu braku blokowania kapilary przez czas 80 minut. Wyniki przeprowadzonych pomiarów przedstawiono na rysunku 2.

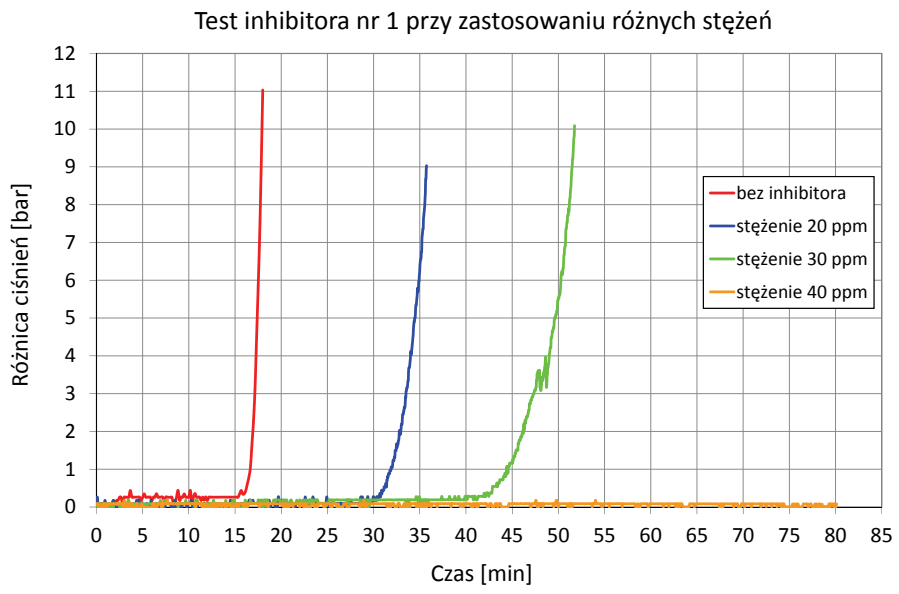

Rys. 2. Przebieg badania inhibitora nr 1 dla różnych stężeń

Fig. 2. The course of the inhibitor 1 test for various concentrations

\section{Test inhibitora $\mathrm{nr} 2$}

Kolejnym badanym środkiem był inhibitor o numerze 2 . Podobnie jak w poprzednim przypadku jest to produkt handlowy, którego główny składnikiem jest poli(kwas asparaginowy) o średniej masie cząsteczkowej wynoszącej 5000 daltonów. Produkt jest nietoksyczny, przyjazny dla środowiska, biodegradowalny i nieulegający bioakumulacji. Wykazuje właściwości inhibitora korozji oraz inhibitora osadów siarczanowych i węglanowych. Podobnie jak poprzednio badania wykonano dla trzech stężeń (20 ppm, 40 ppm i 50 ppm). Dawkę zwiększano aż do momentu osiągnięcia pięciokrotności czasu blokowania kapilary dla próbki bez dodatku inhibitora.

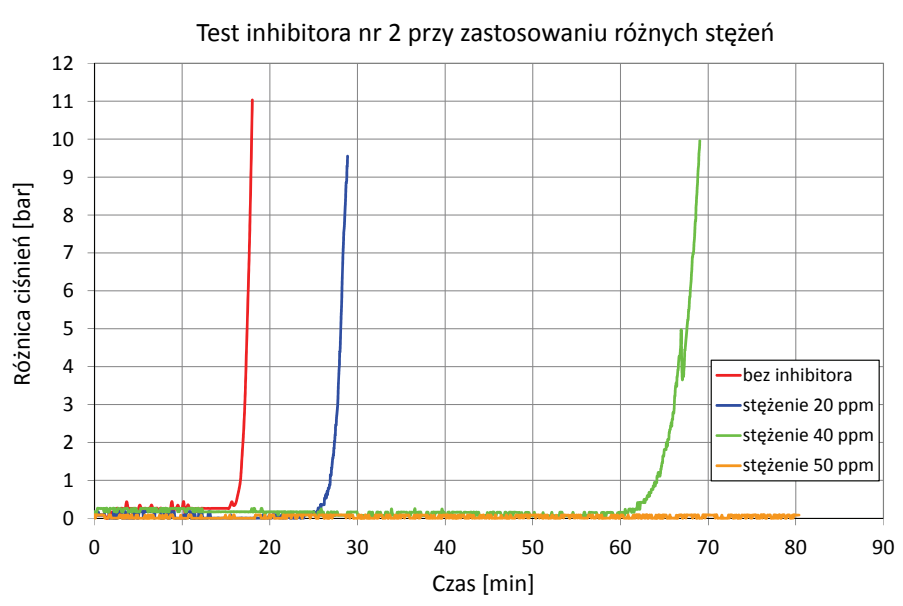

Rys. 3. Przebieg badania inhibitora nr 2 dla różnych stężeń

Fig. 3. The course of the inhibitor 2 test for various concentrations

\section{Test inhibitora nr 3}

Przeprowadzono również badania inhibitora oznaczonego jako nr 3. Środek ten jest pochodną kwasu bursztynowego, otrzymaną w reakcji bezwodnika alkenylobursztynowego $\mathrm{z}$ dietylenotriaminą. Badania wykonano w trzech stężeniach (100 ppm, 400 ppm i 1000 ppm). Niestety pomimo znacznego zwiększenia dawki inhibitora nie zauważono jakiejkolwiek zmiany w wytrącaniu się osadów nieorganicznych w stosunku do próby zerowej. Jedynym efektem działania inhibitora była zmiana we wzroście różnicy ciśnień. W przypadku próby zerowej wzrost był bardzo gwałtowny i niemal natychmiast następowało blokowanie kapilary. Inhibitor nr 3 sprawił, że wzrost ciśnienia następował w łagodniejszy sposób. Jest to szczególnie widoczne na rysunku 4.

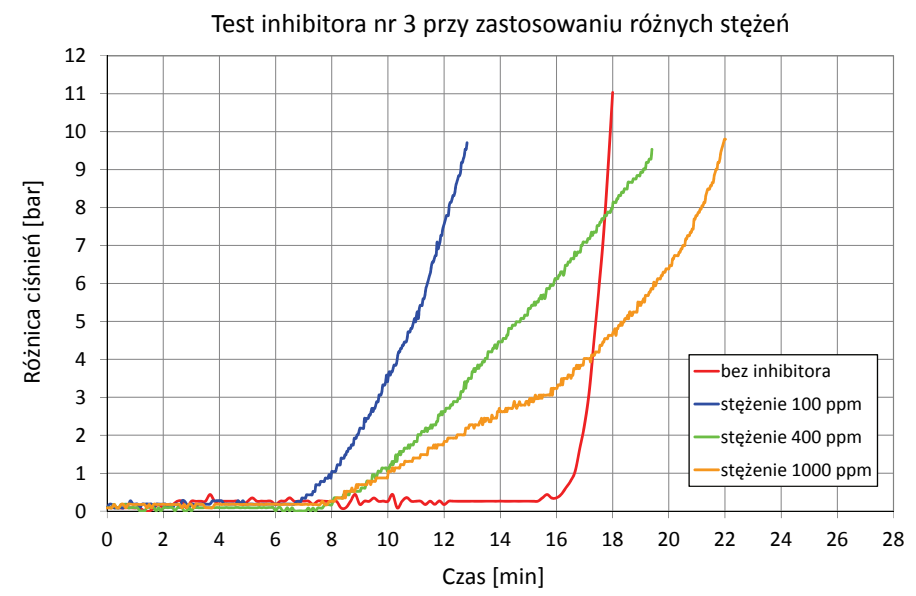

Rys. 4. Przebieg badania inhibitora nr 3 dla różnych stężeń

Fig. 4. The course of the inhibitor 3 test for various concentrations 


\section{Test inhibitora $\mathrm{nr} 4$}

Jako ostatni inhibitor przedstawiony w niniejszej pracy przebadano środek nr 4. Produkt ten jest pochodną kwasu bursztynowego, otrzymaną w reakcji bezwodnika alkenylobursztynowego z N,N'-bis-(3-aminopropylo)-etylenodiaminą. Podobnie jak w poprzednim przypadku badania wykonano dla trzech stężeń (100 ppm, 400 ppm i 1000 ppm). Niestety pomimo znacznego zwiększenia stężenia nie zauważono jakiejkolwiek zmiany w wytrącaniu się osadów nieorganicznych w stosunku do próby zerowej. Dokonano także badania przy zastosowaniu dawki $400 \mathrm{ppm}$ w temperaturze $70^{\circ} \mathrm{C}$. Nie wydłużyło to znacznie czasu przepływu solanek przez kapilarę. Największa różnica występuje w charakterze obu krzywych. W temperaturze $90^{\circ} \mathrm{C}$ blokowanie następowało stopniowo i przez dłuższy czas, natomiast w przypadku temperatury $70^{\circ} \mathrm{C}$ jest to przebieg znacznie gwałtowniejszy. Charakterystykę wykonanych badań zobrazowano na rysunku 5 .

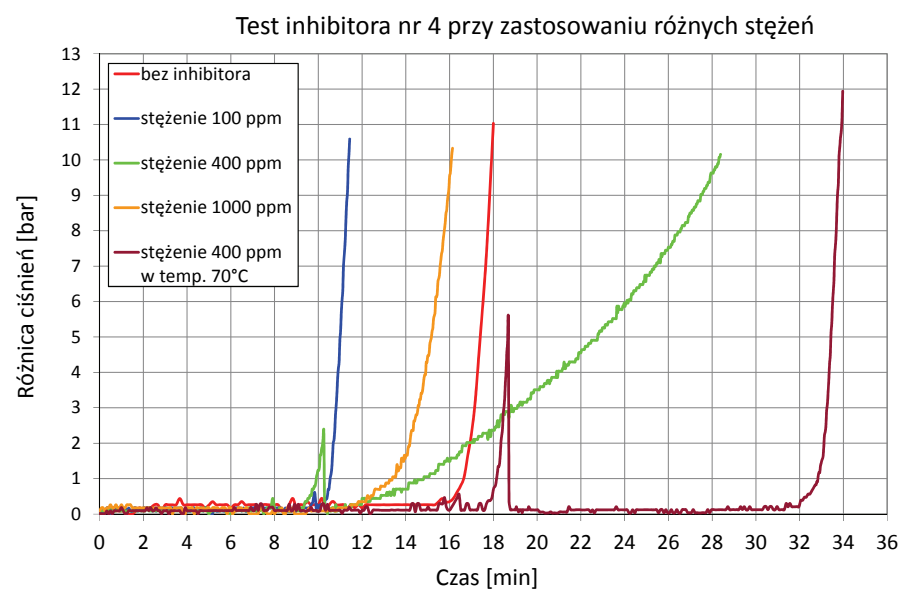

Rys. 5. Przebieg badania inhibitora nr 4 dla różnych stężeń

Fig. 5. The course of the inhibitor 4 test for various concentrations

\section{Podsumowanie}

W ramach wykonanych prac nad określaniem skuteczności działania inhibitorów osadów nieorganicznych w warunkach testu dynamicznego zaprojektowano i wykonano nowe stanowisko badawcze. Dzięki zastosowaniu aparatury do badań PVT możliwy jest szeroki zakres ustalania warunków ciśnienia i temperatury pomiaru. Stanowisko to umożliwia prowadzenie testów zgodnie z zaleceniami przedstawionymi w dokumencie NACE TM0197-2010, No. 21228. W pierwszej kolejności wykonano szereg badań w celu wypracowania metodyki oraz wyznaczenia próby zerowej, następnie dokonano pomiarów dla różnych inhibitorów w co najmniej kilku stężeniach. Wszystkie przebadane środki sprawdzono w aspekcie skuteczności inhibitowania węglanu wapnia. W artykule zestawiono inhibitory, które minimalizowały ryzyko wytrącania się osadów, oraz takie, które powodowały szybsze blokowanie kapilary niż w przypadku próbki zerowej. Dobór odpowiednich solanek i warunków (ciśnienie, temperatura, przepływ) prowadzenia testu dynamicznego potwierdził możliwość oceny inhibitorów pod względem skuteczności zapobiegania wytrącaniu się osadów nieorganicznych.

Artykuł powstał na podstawie pracy statutowej pt.: Badania skuteczności działania inhibitorów osadów nieorganicznych $w$ warunkach testu dynamicznego - praca INiG - PIB na zlecenie MNiSW; nr zlecenia: 0045/KB/17, nr archiwalny: DK-4100-32/17.

\section{Literatura}

Bazin B., Kohler N., Zaitoun A., Johnson T., Raaijmakers H., 2004. A new class of green mineral scale inhibitors for squeeze treatments. Society of Petroleum Engineers. DOI: 10.2118/87453-MS.

Cushner M.C., Przybylinski J.L., Ruggeri J.W., 1988. How temperature and $\mathrm{pH}$ affect the performance of barium sulfate inhibitors. Paper NAC 428. Presented at NACE Corrosion $/ 88$.

Frenier W.W., Ziauddin M., 2008. Formation, removal, and inhibition of inorganic scale in the oilfield environment. Society of Petroleum Engineers. ISBN: 978-1-55563-140-6.

Gaździk B., Pajda M., 2013. Wpływ środków powierzchniowo czynnych o działaniu dyspergującym na właściwości fizykochemiczne i funkcjonalne inhibitorów parafin do wysokoparafinowych rop naftowych. Nafta-Gaz, 4: 319-328.

Graham G.M., Gyani A., Jordan M.M., Strachan C., McClure R., Littlehales I.J., Fitzgerald A., 2002. Selection and application of a non-damaging scale inhibitor package for pre-emptive squeeze in Mungo production wells. Society of Petroleum Engineers. DOI: $10.2118 / 74665-\mathrm{MS}$

Hamouda A.A., 1989. Insight into sulfate in high-salinity producers and selection of scale inhibitor. Society of Petroleum Engineers. DOI: $10.2118 / 19764-P A$.

Jensen K.M., Kelland M.A., 2012. A new class of hyperbranched polymeric scale inhibitors. Journal of Petroleum Science and Engineering, 94-95: 66-72.

Khormali A., Petrakov D.G., Moghaddam R.N., 2017. Study of adsorption/desorption properties of a new scale inhibitor package to prevent calcium carbonate formation during water injection in oil reservoirs. Journal of Petroleum Science and Engineering, 153: $257-267$.

Kuśnierczyk J., 2017. Badania skuteczności działania inhibitorów osadów nieorganicznych w warunkach testu dynamicznego. Dokumentacja Instytutu Nafty i Gazu - PIB, nr zlecenia 0045/ KB/17, nr archiwalny DK-4100-32/17. Kraków.

Kuśnierczyk. J., 2018. Badania skuteczności działania inhibitorów siarczanu baru i strontu w warunkach testu dynamicznego. Dokumentacja Instytutu Nafty i Gazu - PIB, nr zlecenia 0002/ KB/18, nr archiwalny DK-4100-2/18. Kraków.

Liu X., Chen P., Montgomerie H., Hagen T., Wang B., Yang X., 2012. Understanding mechanisms of scale inhibition using newly developed test method and developing synergistic combined scale inhibitors. Society of Petroleum Engineers. DOI: 10.2118/156008-MS.

Luo H., Chen D., Yang X., Zhao X., Feng H., Li M., 2015. Synthesis and performance of a polymeric scale inhibitor for oilfield application. Journal of Petroleum Exploration and Production Technology, 5: 177-187. 
Mazela W., Krasodomski W., Pajda M., 2012. Ocena efektywności rozdzielania emulsji woda-ropa naftowa za pomocą demulgatorów zawierających dendrymery. Nafta-Gaz, 10: 674-683.

Mazela W., Kuśnierczyk J., 2018. Dynamiczny test oceny inhibitorów osadów nieorganicznych - dobór warunków testu. Przemyst Chemiczny, 6: 949-952.

Oddo J.E., Gerbino A.J., Tomson M.B., 1993. Inhibition of $\mathrm{BaSO}_{4}$ precipitation at high temperature, pressure and T.D.S. Paper NACE 461. Presented at NACE Corrosion/93.

Pajda M., Mazela W., Krasodomski W., 2013. Rozdział emulsji woda-ropa naftowa za pomocą czynników fizycznych. NaftaGaz, 12: 923-928.

Schalge A.L., Dormish F.L., 1989. The evaluation of scale inhibitors for high $\mathrm{BaSO}_{4}$ scaling potential using a new tube/filter blocking apparatus. Society of Petroleum Engineers. DOI: 10.2118/18490-MS.

Schilter R., Yang Ch., Hill M., Watson P., Mac Ewen K., Almond S., 2014. Field-detectable scale inhibitor for severe oilfield environments. Society of Petroleum Engineers. DOI: 10.2118/170296-MS.

Senthilmurugan B., Ghosh B., Sanker S., 2011. High performance maleic acid based oil well scale inhibitors - Development and comparative evaluation. Journal of Industrial and Engineering Chemistry, 17: 415-420.

Shanthana Lakshmi D., Senthilmurugan B., Drioli E., Figoli A., 2013. Application of ionic liquid polymeric microsphere in oil field scale control process. Journal of Petroleum Science and Engineering, 112: 69-77.

Szymczak S., Shen D., Higgins R., Gupta D.V.S., 2013. Minimizing environmental and economic risks with a proppant-sized solid-scale-inhibitor additive in the Bakken Formation. Society of Petroleum Engineers. DOI: 10.2118/159701-PA.

Tiu B.D.B., Advincula R.C., 2015. Polymeric corrosion inhibitors for the oil and gas industry: Design principles and mechanism. Reactive and Functional Polymers, 95: 25-45.

Todd M.J., Wylde J.J., Strachan C.J., Moir G., Thornton A., Goulding J., 2012. Phosphorus functionalised polymeric scale inhibitors, further developments and field deployment. Society of Petroleum Engineers. DOI: 10.2118/154135-MS.

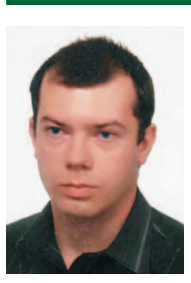

Mgr inż. Jerzy KUŚNIERCZYK

Specjalista badawczo-techniczny w Zakładzie

Badania Złóż Ropy i Gazu

Instytut Nafty i Gazu - Państwowy Instytut Badawczy ul. Lubicz 25 A

31-503 Kraków

E-mail: jerzy.kusnierczyk@inig.pl

Dr inż. Wojciech MAZELA
Adiunkt, kierownik Laboratorium Nowych
Technologii Odnawialnych
Instytut Nafty i Gazu - Państwowy Instytut Badawczy
ul. Lubicz 25 A
31-503 Kraków
E-mial: wojciech.mazela@inig.pl

pobór wgtębnych i powierzchniowych próbek ptynów złożowych;

- kompleksowe badania i analizy zmian fazowych próbek ptynów złożowych na zestawie aparatów PVT firmy Chandler i Ruska;

· modelowanie procesu wypierania ropy gazem na fizycznym modelu ztoża tzw. „cienka rurka”;

- pomiar lepkości ropy wiskozymetrem kulkowym lub kapilarnym w warunkach PT;

optymalizacja procesów powierzchniowej separacji ropy naftowej;

- laboratoryjne i symulacyjne badania warunków wytrącania się parafin, asfaltenów w ropie oraz tworzenia się hydratów w gazie;

- badanie skuteczności działania chemicznych środków zapobiegających tworzeniu się hydratów;

- laboratoryjne modelowanie procesów wypierania ropy gazem w warunkach zmieszania faz;

- badanie procesów sekwestracji $\mathrm{CO}_{2}$ w solankowych poziomach wodonośnych, nasyconych gazem ziemnym;

- badania na dtugich rdzeniach wiertniczych dla oceny efektywności metod zwiększenia stopnia odzysku ropy.

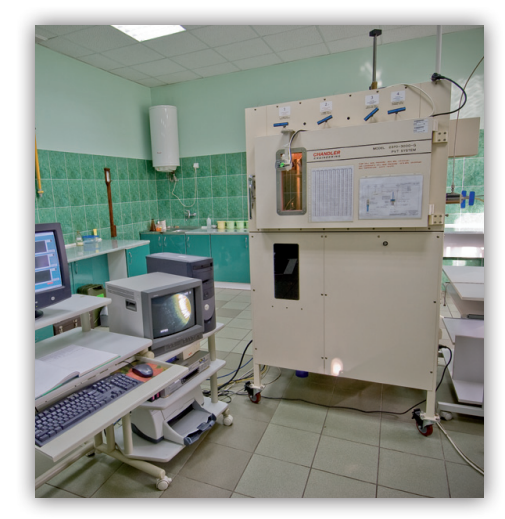

Kierownik: dr inż. Marcin Warnecki Adres: ul. Armii Krajowej 3, 38-400 Krosno

Telefon: 134368941 w. 5226, 5231, 5224 Faks: 134367971 E- mail: marcin.warnecki@inig.pl 